University of Nebraska - Lincoln

DigitalCommons@University of Nebraska - Lincoln

Publications, Agencies and Staff of the U.S.

Department of Commerce

U.S. Department of Commerce

1993

\title{
Global Snow Cover Monitoring: An Update
}

David A. Robinson

Department of Geography, Rutgers University, New Brunswick, New Jersey

Kenneth F. Dewey

University of Nebraska-Lincoln, kdewey@unl.edu

Richard R. Heim, Jr.

Global Climate Lab, NCDC, Asheville, North Carolina

Follow this and additional works at: https://digitalcommons.unl.edu/usdeptcommercepub

Part of the Environmental Sciences Commons

Robinson, David A.; Dewey, Kenneth F.; and Heim, Jr., Richard R., "Global Snow Cover Monitoring: An Update" (1993). Publications, Agencies and Staff of the U.S. Department of Commerce. 40.

https://digitalcommons.unl.edu/usdeptcommercepub/40

This Article is brought to you for free and open access by the U.S. Department of Commerce at DigitalCommons@University of Nebraska - Lincoln. It has been accepted for inclusion in Publications, Agencies and Staff of the U.S. Department of Commerce by an authorized administrator of DigitalCommons@University of Nebraska - Lincoln. 


\section{Global Snow Cover Monitoring: An Update}

\begin{abstract}
Accurate monitoring of the large-scale dimensions of global snow cover is essential for understanding details of climate dynamics and climate change. Presently, such information is gathered individually from ground station networks and satellite platforms. Efforts are in progress to consolidate and analyze long-term station records from a number of countries. To gain truly global coverage, however, satellite-based monitoring techniques must be employed. A 27-year record of Northern Hemisphere continental snow cover produced by the National Oceanic and Atmospheric Administration (NOAA) is the longest such environmental record available. Records of Southern Hemisphere continental cover and snow on top of Arctic sea ice have been produced by similar means for a portion of this interval. The visible imagery charting technique used to generate these data provides information on snow extent but not on snow volume. Satellite microwave analyses over Northern Hemisphere lands show some promise in this regard, however, large-scale monitoring of snow extent with microwave data remains less accurate than visible charting.

This paper updates the status of global snow cover monitoring, concentrating on the weekly snow charts prepared by NOAA and discussing a new and consistent record of monthly snow cover generated from these weekly charts. The NOAA charts show a reduction of hemispheric snow cover over the past five years, particularly in spring. Snow areas from the NOAA product are then compared with values derived using passive microwave data. The latter consistently reports less snow cover than the more accurate visible product. Finally, future snow monitoring initiatives are recommended. These include continuing the consistent NOAA product until an all-weather all-surface product is developed. The latter would use multiple data sources and geographic information systems techniques. Such an integrative product would need extensive comparisons with the NOAA product to ensure the continued utility of the lengthy NOAA observations in studies of climate change. In a retrospective sense, satelite charts from the middle 1960 s to early 1970 s need reevaluation and techniques to merge satellite products with historic station time series must be developed.
\end{abstract}

\section{Introduction}

Across the middle and high latitudes of the Northern Hemisphere, the impact of snow on humans and the environment is considerable. Falling snow or snow lying on the ground or on ice influences hydrologic,

\footnotetext{
*Department of Geography, Rutgers University, New Brunswick, New Jersey

+Department of Geography, University of Nebraska, Lincoln, Nebraska

${ }^{\star \star}$ Global Climate Lab, NCDC, Asheville, North Carolina
}

biologic, chemical, and geologic processes at and near the surface of the earth. Snow impacts activities as diverse as engineering, agriculture, travel, recreation, commerce, and safety. Empirical and modeling studies show the influential role of snow cover within the global heat budget (Berry 1981; Walsh et al. 1985; Robinson and Kukla 1985; Kukla et al. 1986; Barnett et al. 1989). This is expressed chiefly through increased surface albedo in snow-covered regions. Global models of human-induced climate change suggest enhanced warming in current regions of ephemeral snow cover (Mitchell et al. 1990; Gates et al. 1992). For this reason snow cover has been recommended as a useful index for detecting and monitoring such change (Barry 1985; Schlesinger 1986).

Accurate snow cover information is essential for understanding details of climate dynamics and climate change. Snow observations should be as lengthy and geographically extensive as possible. Ground station measurements of snow cover have been made for up to a century in some countries, and recently we and others have begun to consolidate and quality control these data (Robinson 1993a). The spatial coverage provided by the stations, however, is generally limited to low elevation regions of the Northern Hemisphere midlatitudes and to snow courses in mountainous regions. An urban bias may also exist, resulting in an underrepresentation of snow. A more complete hemispheric view of snow cover needs information from satellite-borne sensors. Currently, visible satellite images provide the most accurate information on snow cover extent; however, this data source extends back only approximately three decades. Microwave-derived estimates of snow extent and volume are relatively accurate over some regions but are available only since the late 1970s.

Only Northern Hemisphere lands have been continuously monitored for snow extent since the late 1960s (Dewey and Heim 1981; Iwasaki 1991), although we have examined snow for select intervals over Southern Hemisphere lands (excluding Antarctica) (Dewey and Heim 1983) and Arctic sea ice (Robinson et al. 1992). There is also a daily U.S. Air Force snow product that relies heavily on surfacebased observations as input into a numerical model that creates daily charts with global coverage (Hall 1986). Disadvantages of these charts include a reli- 
ance on extrapolations and climatology in data-sparse regions (McGuffie and Robinson 1988). Recently, an improved interpolation scheme incorporating horizontal and vertical components has been added to the model (Armstrong and Hardman 1991). A method to estimate depth using passive microwave data has also been proposed to reduce the reliance on climatology but has yet to be implemented.

In this paper we examine visible satellite observations of snow cover over Northern Hemisphere lands and, using this information, evaluate monthly snow extents from 1972 to 1992. A discussion of satellite passive microwave efforts to identify snow and a comparison of microwave and visible products follows. Finally, we recommend ongoing and retrospective monitoring initiatives.

\section{Charting from visible data}

Visible satellite data provide continental coverage of snow extent at a relatively high spatial resolution. Snow is identified by recognizing characteristic textured surface features and brightness. Surface albedo and percent of snow coverage (patchiness) are also gleaned from the data. Shortcomings include 1) the inability to detect snow cover when solar illumination is low or when skies are cloudy, 2) the underestimation of cover where dense forests mask the underlying snow, 3) ambiguities in the recognition and demarcation of patchy snow cover, 4) difficulties in discriminating snow from clouds in mountainous regions and in uniform lightly vegetated areas that have a high surface brightness when snow covered, and 5) the lack of all but the most general information on snow depth (Kukla and Robinson 1981; Dewey and Heim 1982).

\section{a. NOAA snow charts}

The National Oceanic and Atmospheric Administration (NOAA) began mapping snow cover over Northern Hemisphere lands in 1966 (Matson et al. 1986). The weekly charts resulting from this effort continue to be generated operationally and remain the only such hemispheric product. They comprise the longest satellite-based environmental record available.

NOAA charts are based on a visual interpretation of photographic copies of visible imagery by trained meteorologists. The subpoint resolution of the meteorological satellites used prior to 1972 was about $4 \mathrm{~km}$. The Very High Resolution Radiometer (VHRR) launched in 1972 provided imagery with a spatial resolution of $1.0 \mathrm{~km}$. Since November 1978 the Advanced VHRR has provided $1.1-\mathrm{km}$ resolution data. Imagery is examined daily and charts show snow boundaries on the last day of the chart week that the surface in a region is seen (Fig. 1). Since May 1982 , the date when a particular region is last observed has been placed on the charts. An examination of these dates shows the snow coverage to best represent that of the fifth day of the chart week.

In early years the snow extent was underestimated on the NOAA charts, especially during fall. Charting improved considerably in 1972 with the deployment of the VHRR sensor and the increased experience among analysts in recognizing snow-covered ground. Since then we consider the charts suitable for continentalscale climate studies (Kukla and Robinson 1981), particularly where 1) skies are frequently clear, as is common in spring near the snow line, 2) solar zenith angles are relatively low and illumination is high, 3) the snow cover is reasonably stable or changes slowly, and 4) pronounced local and regional signatures are present owing to the distribution of vegetation, lakes, and rivers. The NOAA charts are digitized weekly using the National Meteorological Center's primitive equation grid. This is an $89 \times 89$ cell Northern Hemisphere grid having a polar stereographic projection. Cell resolution ranges from $16000 \mathrm{~km}^{2}$ to $42000 \mathrm{~km}^{2}$. Only cells interpreted to be at least $50 \%$ snow covered are considered snow covered.

Figure 2 shows the mean position of the North American snow line for four months of the year. Snow lines are derived from 20 years of NOAA digital data by calculating the percentage of time each digitized cell is recognized as snow covered. To acquire accurate monthly snow extents, we have developed a new routine (Robinson 1993b). This follows our discovery of a major inconsistency in NOAA's calculations of monthly snow cover areas (Robinson et al. 1991). Before 1981 NOAA calculated continental areas from monthly summary charts, which consider a cell to be snow covered if snow is present on two or more weeks during a given month (Dewey and Heim 1982). Since 1981 NOAA has produced monthly areas by averaging areas calculated from weekly charts. A comparison of these two methodologies shows areas computed using the monthly approach to be from several hundred thousand to over three million square kilometers greater than those calculated using weekly areas. The offsets are not consistent. Also contributing to the problem are 53 cells (covering $1.8 \times 10^{6} \mathrm{~km}^{2}$ ) that are not considered consistently in the area calculations throughout the period of record. In 1981 NOAA changed their land mask; 26 land cells were reclassified as water and 27 new land cells were added. As discussed in the following, neither of the NOAA masks is accurate; both fail to accurately identify all land ( $\geq 50 \%$ land) and water cells.

Our new consistent methodology (Rutgers routine) weekly calculates areas from the digitized snow files 


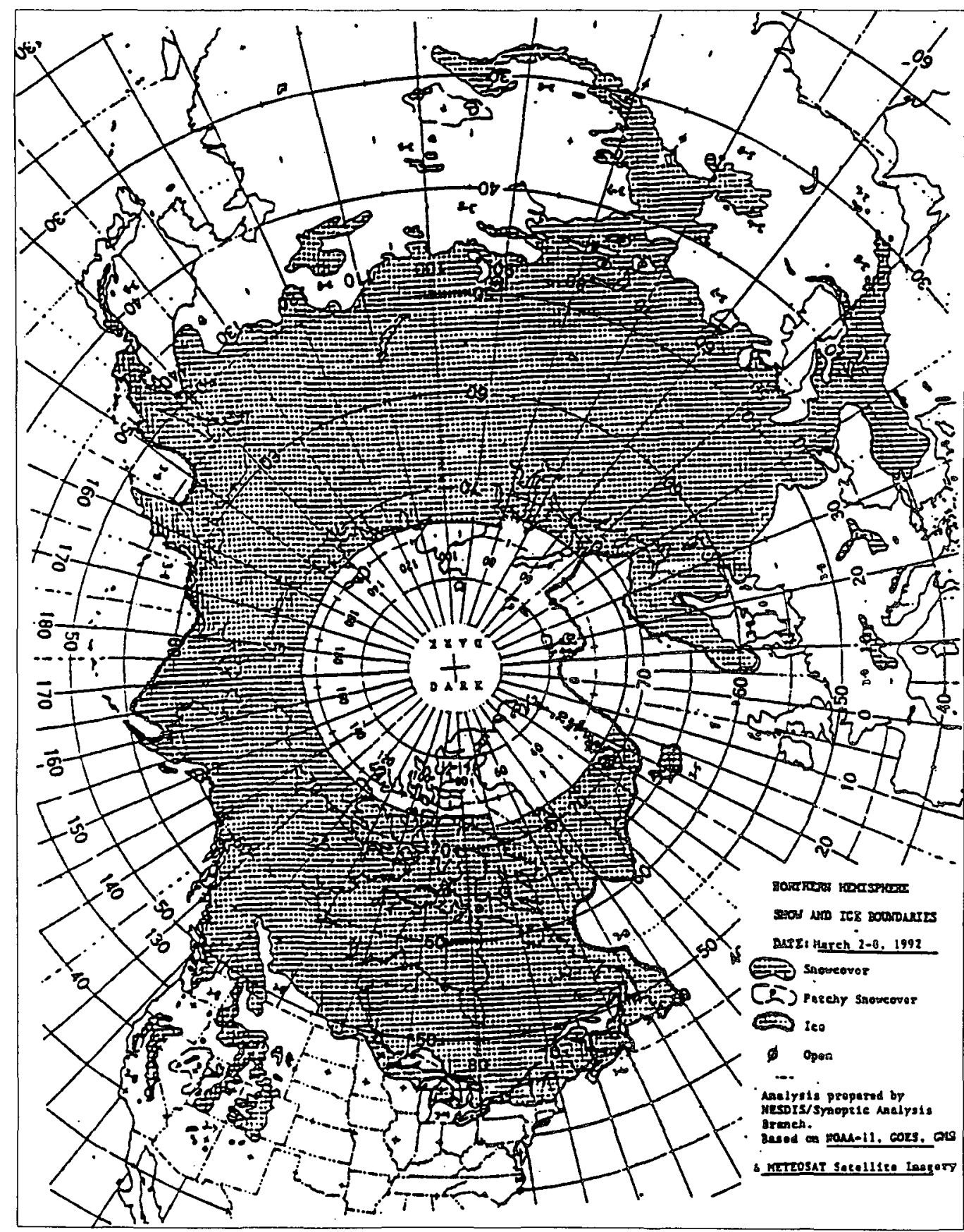

FIG. 1. NOAA snow chart for 2-8 March 1992. The size of the chart shown here is approximately $20 \%$ of the original.

and weights them according to the number of days of a chart week falling in the given month. A chart week is considered to center on the fifth day of the published chart week. No weighting has been employed in either of the NOAA routines.

In addition, we have developed a definitive land mask at Rutgers using digital map files analyzed on a geographic information system (GIS). We calculated the percentage of land in each of the 7921 NMC grid cells using the National Geophysical Data Center's 5min resolution ETOPO5 file as the primary data source. As this file does not include large interior lakes, the Navy Fleet Numerical Oceanography Center's 10-min resolution Primary Terrain Cover Types file was used to account for these water bodies. Some 48 cells poleward of approximately $30^{\circ} \mathrm{N}$, which had been considered land in the pre-1981 NOAA or in the 1981. to-present NOAA mask, are actually predominantly 
water covered. Conversely, 54 land cells were considered water on one or both NOAA masks, and these required a first-time analysis to determine whether they might be snow covered. This was accomplished by selecting nearest representative land cells (cells that NOAA has continually charted as land) and assigning their snow status to the "new" land cells. Spot checks of a number of hard copy weekly charts prove this to be an adequate approach. NOAA plans to begin using this mask in the near future.

\section{b. Continental snow cover from NOAA charts: 1972 1992}

According to values generated using the Rutgers routine, the extent of snow cover over Northern Hemisphere lands is greatest in January. On average, 46.5 million $\mathrm{km}^{2}$ of Eurasia and North America are snow covered in this month, with February a close second, averaging 46.0 million $\mathrm{km}^{2}$ (Table 1, Fig. 3). August has the least cover, averaging 3.8 million $\mathrm{km}^{2}$, the majority of this being snow on top of the Greenland ice sheet. The past two decades of monthly data are close to normally distributed, and monthly standard deviations range from 1.0 million $\mathrm{km}^{2}$ in August to 2.9 million $\mathrm{km}^{2}$ in October. The annual mean cover is 25.3 million $\mathrm{km}^{2}$ with a standard deviation of 1.1 million $\mathrm{km}^{2}$. The snowiest year was 1978 with a mean of 27.4 million $\mathrm{km}^{2}$, with 1990 the least snowy at 23.2 million $\mathrm{km}^{2}$.

Twelve-month running means of continental snow extent best illustrate the periods of above-normal cover that occurred in the late 1970s and mid-1980s

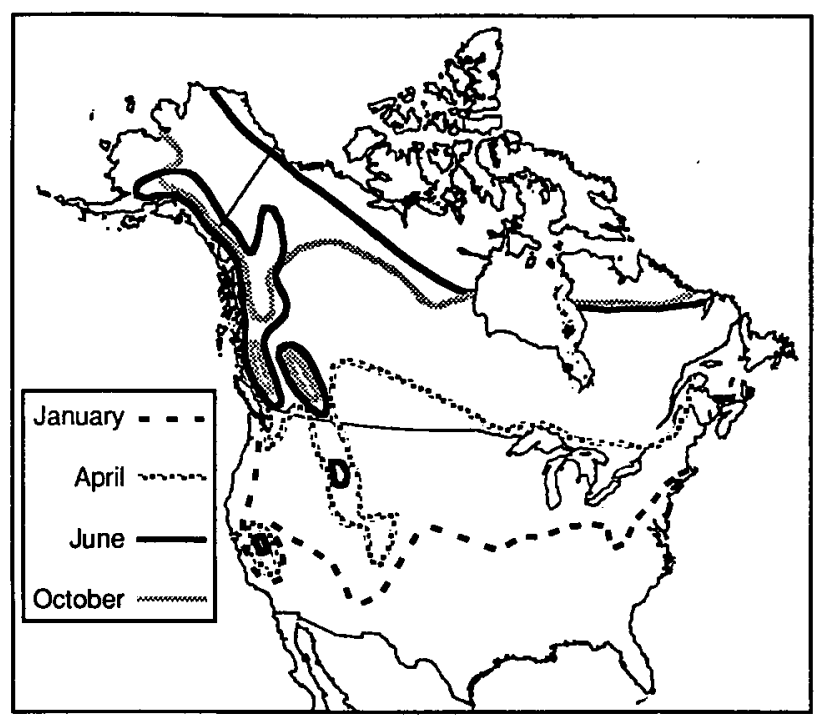

FIG. 2. Mean North American snow lines for October, January, April, and June. Lines are derived from NOAA weekly snow charts covering the interval from January 1971 through June 1990. The mean snow line is defined as the isoline denoting a $50 \%$ frequency of snow cover.

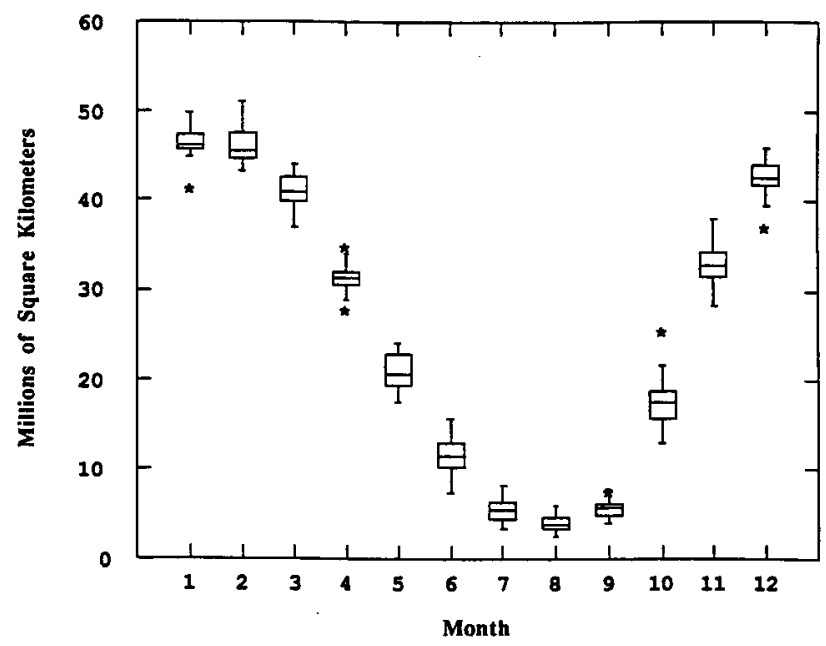

FIG. 3. Monthly snow cover over Northern Hemisphere lands (including Greenland) between January 1972 and December 1992. The median area of cover is the horizontal line within the 12-monthly boxes, and the interquartile range (ICR) is between the top and bottom of the box. Whiskers show the extreme values between +1 and +1.5 ICR and -1 and -1.5 ICR, and asterisks show values in individual years falling outside of the \pm 1.5 ranges. Values are calculated from NOAA weekly snow charts.

(Fig. 4). Intervals with lower snow extents include the mid-1970s and early 1980s; however, neither approach the deficit of snow cover observed in recent years. Of the 65 months between August 1987 and December 1992, only 8 months had above-normal snow cover. Three of these were September, November, and December 1992. The lowest year on record was 1990 , when monthly minima occurred in 8 months (Table 1). Spring cover has shown pronounced deficits over the past 5 years in Eurasia and 6 years in North America. Areas in these springs have been at or below lows established before this period (Fig. 5). Fall and summer cover has also been low in recent years, while winter cover has been close to average. The reduced snow extent in recent years has coincided with some of the warmest surface air temperatures of the past century (Jones et al. 1991). We have observed a striking inverse relationship between hemispheric snow extent and surface air temperature over the past two decades (Robinson et al. 1991).

\section{Charting from passive microwave data}

Microwave radiation emitted by earth's surface is largely unobstructed by weather effects as it penetrates the winter atmosphere. This makes the discrimination of snow cover from passive microwave satellite data possible by recognizing differences in emissivity between snow-covered and snow-free sur- 


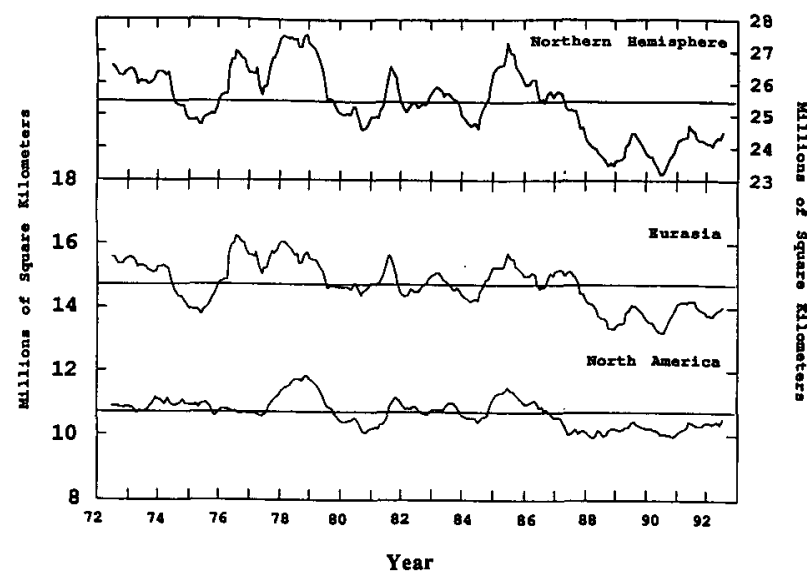

FIG. 4. Twelve-month running means of snow cover over Northern Hemisphere lands (including Greenland) for the period January 1972 through December 1992. Running means are also shown for Eurasia and North America (including Greenland). Values are plotted on the seventh month of the 12-month interval and are calculated from NOAA weekly snow charts.

faces. The spatial extent as well as the depth or water equivalent of the snowpack are estimated using equations that employ radiation sensed by multiple channels in the microwave portion of the spectrum (e.g., Kunzi et al. 1982; Chang et al. 1987; McFarland et al. 1987). Snow estimates from satellite-borne microwave sensor data have been available since the launch of the Scanning Multichannel Microwave Radiometer (SMMR) in late 1978. The spatial resolution of the data is several tens of kilometers. Since 1987 the Special Sensor Microwave Imager $(\mathrm{SSM} / \mathrm{l})$ has provided information to determine snow extent and volume. The lack of sufficient coverage of ground truth snow depth or volume data makes an adequate assessment of the reliability of microwave estimates uncertain on regional and larger scales. Therefore, the remainder of this discussion focuses on the microwave monitoring of snow extent.

As with visible products, the microwave monitoring of snow extent has limitations. Data resolution makes the detailed recognition of snow cover difficult, particularly where snow is patchy, and it is difficult to identify shallow or wet snow using microwaves. Because of region-specific differences in land cover and snowpack properties, a single algorithm cannot adequately estimate snow cover across Northern Hemisphere lands (see the following). Studies of a regional nature that address these differences encompass landscapes as diverse as mountains (Chang et al. 1991), the Tibetan Plateau (Robinson et al. 1984; Robinson and Spies 1993); forest (Hall et al. 1982; Hallikainen and Jolma 1986), tundra (Hall et al. 1986), and prairie (Goodison 1989).

\section{a. Continental snow cover from NASA charts: 1978- 1987}

Monthly charts of Northern Hemisphere continental snow extent have been produced from SMMR data by a team of NASA scientists (Chang et al. 1990). This is the only such time series available to date and covers the interval from November 1978 through August 1987. A single algorithm is used to estimate snow depth on $a .5^{\circ} \times 0.5^{\circ}$ grid. Monthly values are averages of depths for the five or six pentad charts centered in a given month (SMMR data were gathered every other day and three of these passes are used for each pentad chart; there is a one-day gap between each pentad). Cells having an average depth of 2.5 $\mathrm{cm}$ are considered snow covered all month. This results in a positive bias to the snow areas, especially in areas where snow cover fluctuates. Despite this
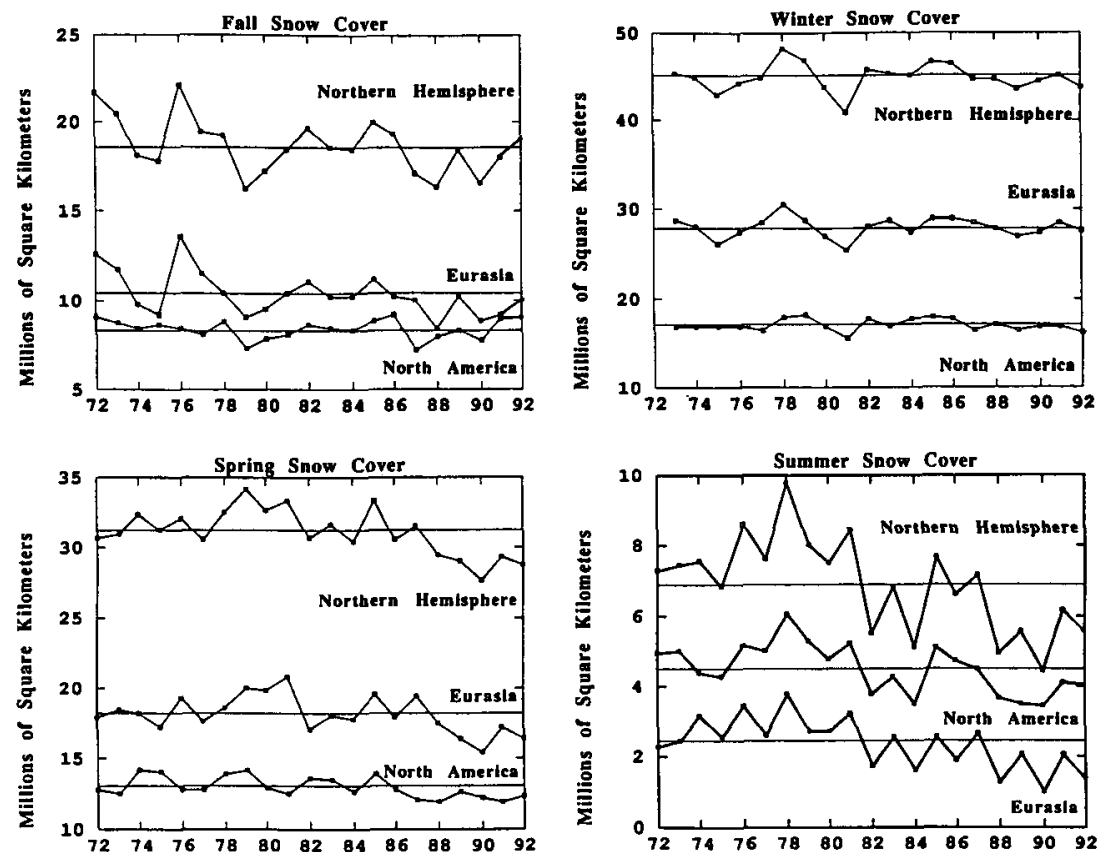

FlG. 5. Seasonal time series of snow cover over Eurasia and North America (Greenland is excluded) (winter: Dec-Feb; spring: Mar-May; summer: June-Aug; fall: Sep-Nov). Values are calculated from NOAA weekly snow charts. 
bias, NASA mean monthly snow cover for Northern Hemisphere lands (exclusive of Greenland) runs from less than 1 million to as much as 13 million $\mathrm{km}^{2}$ below NOAA areas for the nine years of coincidental estimates. These absolute differences are greatest in the late fall and early winter. In a relative sense, NASA microwave areas are between $80 \%$ and $90 \%$ of NOAA visible values in winter and spring, $20 \%$ to $40 \%$ of the visible estimates in summer, and $40 \%$ to $70 \%$ of visible areas in fall (Fig. 6). Wet and shallow snows may explain the significant disparities in the latter two seasons. Both are difficult if not impossible to monitor using a passive microwave approach. Depth may be the most important of these two variables, given the better agreement in spring, although it has been suggested that unfrozen soil beneath the pack is a major contributor to underestimates during fall ( $B$. Goodison 1993, personal communication). There may also be an overestimation of summer continental snow cover in the NOAA product due to difficulties in distinguishing between frozen water bodies and snowfreeland inArcticregions (e.g., Canadian archipelago).

Snow monitoring employing SSM/I data shows the same strengths and liabilities as the SMMR data (Goodison 1989; Hall et al. 1991). The SSM/I has 19 and $37 \mathrm{GHz}$ channels; thus, SMMR algorithms perform much the same as with the 18 and $37 \mathrm{GHz}$ channels. In addition, the $85 \mathrm{GHz}$ channel on the SSM/ I has shown promise in improving the monitoring of shallow $(<5 \mathrm{~cm})$ snow cover (Nagler and Rott 1991).

\section{Snow monitoring in the 1990 s}

While useful snow data are increasingly being gathered, the need remains to improve ongoing monitoring and to continue assembling and analyzing past observations. Given limited resources these activities must be developed to take best advantage of the data and analytic tools available. With this in mind we make the following recommendations regarding snow monitoring activities and projects for the years ahead.

Rutgers routine.

Maximum (yr) Minimum (yr) Mean Median Std. Dev.

\begin{tabular}{|ccccccc|}
\hline Jan & $49.8(1985)$ & 41.7 & $(1981)$ & 46.5 & 46.1 & 1.8 \\
\hline Feb & $51.0(1978)$ & $43.2(90,92)$ & 46.0 & 45.6 & 2.0 \\
\hline Mar & $44.1(1985)$ & $37.0(1990)$ & 41.0 & 40.8 & 1.9 \\
\hline Apr & $35.3(1979)$ & $28.2(1990)$ & 31.3 & 31.4 & 1.8 \\
\hline May & $24.1(1974)$ & $17.4(1990)$ & 20.8 & 20.6 & 1.9 \\
\hline Jun & $15.6(1978)$ & $7.3(1990)$ & 11.5 & 11.4 & 2.1 \\
\hline Jul & $8.0(1978)$ & $3.4(1990)$ & 5.3 & 5.5 & 1.2 \\
\hline Aug & $5.7(1978)$ & $2.6(1988$, & 3.8 & 3.7 & 1.0 \\
\hline Sep & $7.9(1972)$ & $3.9(1990)$ & 5.6 & 5.6 & 1.1 \\
\hline Oct & $26.1(1976)$ & $13.0(1988)$ & 17.5 & 17.5 & 2.9 \\
\hline Nov & $37.9(1985)$ & $28.3(1979)$ & 33.0 & 32.8 & 2.3 \\
\hline Dec & $46.0(1985)$ & $37.5(1980)$ & 42.6 & 43.0 & 2.3 \\
\hline ANN: NH & $27.3(1978)$ & $23.1(1990)$ & 25.3 & 25.3 & 1.1 \\
\hline ANN: EU & $16.0(1976)$ & $13.1(1990)$ & 14.7 & 14.7 & 0.8 \\
\hline ANN: NA & $11.7(1978)$ & $10.0(1990)$ & 10.6 & 10.7 & 0.4 \\
\hline
\end{tabular}

\section{a. Near real-time monitoring}

1) MaINTAIN THE NOAA VISIBLE

SATELLITE CHARTING EFFORT IN ITS PRESENT FORM

To alter abruptly or, perhaps more seriously, alter subtly the manner in which the NOAA charts are produced would severely weaken what is presently the longest and most consistent satellitederived dataset of any surface or atmospheric variable. Any alteration would require "restarting the clock" and losing precious years when employing snow cover to identify and monitor climate change.

\section{2) DEVELOP AND PRODUCE ALL- \\ WEATHER, ALL-SURFACE SNOW CHARTS}

These charts should incorporate visible and microwave satellite data and station observations and use GIS techniques. At threeto-five-day intervals, these operational global charts would provide the most detailed information pos- 
sible on snow extent, water equivalent and depth, and surface albedo over land surfaces, and, at a minimum, snow extent and albedo over sea ice and the Greenland ice sheet. This effort should be designed to accommodate future improvements in all the realms of snow monitoring, including increased station coverage, operational satellite monitoring of the surface at $1.6 \mu \mathrm{m}$ to better distinguish clouds from snow cover (Bunting and d'Entremont 1982), new regional microwave algorithms, or improved GIS techniques. Charts might also benefit from the use of other data such as precipitation and temperature observations. The charts, whenever developed, should not replace the current NOAA visible product until sufficient coincident observations have been made to assure the continued utility of the lengthy NOAA product in climate change studies.

\section{b. Retrospective monitoring}

1) CONTINUED ASSEMBLY, DIGITIZATION, AND QUALITY CONTROL OF HISTORIC AND RECENT STATION DATA

In addition to addressing data from conventional stations, ground data from snow courses and remote snow measurement networks should be scrutinized. This is exemplified by the current effort to recover snow course data from the former Soviet Union through a cooperative effort between the U.S. National Snow and lce Data Center at the University of Colorado and A. Krenke of the Russian Academy of Science. All of these data, whether gathered daily or monthly, are needed as ground truth when verifying satellite-based efforts, as well as to provide historic perspective when analyzing recent variations. Associated with the latter, techniques need to be developed to merge satellite products with station historic time series.

\section{2) Rechart Northern Hemispheric continental} SNOW COVER FROM 1966 THROUGH 1971

Visible satellite data are available for this interval, albeit at a lower resolution than in recent years. With the improved ability of analysts to recognize snow from clouds or snow-free ground, significant improvements to the early NOAA charts are possible. We also recommend recharting the Tibetan Plateau and adjacent mountains through the middle 1970s and summer high-latitude lands. These endeavors and spot checks across the continents in subsequent years would expand and improve the NOAA time series and would permit establishing quantitative error estimates to this product.

\section{Conclusions}

The recent meager extent of snow cover over Northern Hemisphere lands raises a number of ques-

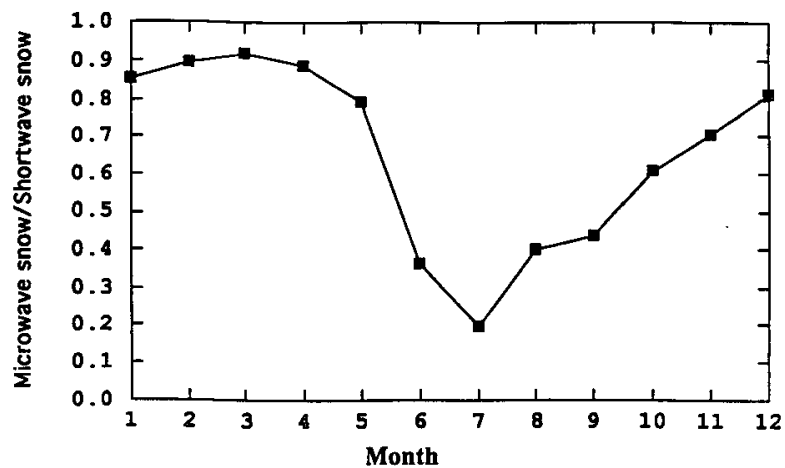

Fla. 6. Ratio of mean monthly snow cover area derived from NASA microwave and NOAA visible charts for Northern Hemisphere lands (excluding Greenland). NOAA values exceed NASA estimates for each month within the November 1978 through August 1987 study period.

tions regarding the natural variability of snow, the potential utility of snow as an indicator of humaninduced climate change, and the role of snow in the climate system and in any future climate change. New studies have provided information about interactions between snow and other components of the climate system (e.g., Yasunari 1987; Robinson and Dewey 1990; Gutzler and Rosen 1992; IPCC 1992; Karl et al. 1993; Leathers and Robinson 1993), but they also illustrate the need for additional snow information. With the ongoing development of station and satellite snow datasets and the promise of continued improvements in analytic techniques, more accurate and extensive information on the extent and physical characteristics of snow cover across continents and sea ice will continue to become available. This information will contribute greatly to gaining greater insight and eventually provide answers to the questions posed above, the most important perhaps being whether snow cover is a credible indicator of climate change.

Acknowledgments. Thanks to G. Stevens at NOAA for supplying digital snow data and to $A$. Frei for assistance in calculating NOAA snow areas. Thanks also to A. Chang at NASA for providing microwave data. This work is supported by NOAA under Grant NA90AA-D-AC518, the Geography and Regional Science Program of the National Science Foundation under Grant SES-9011869, and the NSF Climate Dynamics Program under Grant ATM-9016563.

\section{References}

Armstrong, R., and M. Hardman, 1991: Monitoring global snow cover. Proc. IGARSS '91, Espoo, Finland, IEEE, 1947-1950.

Barnett, T. P., L. Dumenil, U. Schlese, E. Roeckner, and M. Latif, 1989: The effect of Eurasian snow cover on regional and global climate variations. J. Atmos. Sci., 46, 661-685.

Barry, R. G., 1985: The cryosphere and climate change. Detecting 
the Climatic Effects of Increasing Carbon Dioxide. U.S. Dept. of Energy, DOE/ER 0235, 109-148.

Berry, M.O., 1981: Snow and climate. Handbook of Snow. Pergamon Press, 32-59.

Bunting, J. T., and R. P. d'Entremont, 1982: Improved cloud detection utilizing defense meteorological satellite program near infrared measurements. Air Force Geophysics Laboratory Report AFGL-TR-82-0027, $91 \mathrm{pp.}$

Chang, A. T. C., J. L. Foster, and D. K. Hall, 1987: Nimbus-7 derived global snow cover parameters. Anal. Glaciol., 9, 39-45.

,$- \ldots$, and -1990 : Satellite sensor estimates of Northern Hemisphere snow volume. Int. J. Rem. Sen., 11, 167-171.

- - - and A. Rango, 1991: Utilization of surface cover composition to improve the microwave determination of snow water equivalent in a mountain basin. Int. J. Rem. Sen., 12, 23112319.

Dewey, K. F., and R. Heim, Jr, 1981: Satellite observations of variations in Northern Hemisphere seasonal snow cover. NOAA Tech. Rep. NESS 87, Washington, D.C., 83 pp.

$\longrightarrow$, and 1 1982: A digital archive of Northern Hemisphere snow cover, November 1966 through December 1980. Bull. Amer. Meteor. Soc., 63, 1132-1141.

- , and — 1983: Satellite observations of variations in Southern Hemisphere snow cover. NOAA Tech. Rep. NESDIS 1 , Washington, D.C., 20 pp.

Gates, W. L., J. F. B. Mitchell, G. J. Boer, U. Cubasch, and V. P. Meleshko, 1992: Climate modelling, climate prediction and model validation. Climate Change 1992. The Supplementary Report to the IPCC Scientific Assessment, Cambridge University Press, 97-134.

Goodison, B. E., 1989: Determination of areal snow water equivalent on the Canadian prairies using passive microwave satellite data. Proc. IGARSS '89, 3, 1243-1246.

Gutzler, D. S., and R. D. Rosen, 1992: Interannual variability of wintertime snow cover across the Northern Hemisphere. J. Climate, 5, 1441-1447.

Hall, D. K., J. L. Foster, and A. T. C. Chang, 1982: Measurement and modeling of microwave emission from forested snowfields in Michigan. Nordic Hydrol., 13, 129-138.

- A. T. C. Chang, and J. L. Foster, 1986: Detection of the depth hoar layer in the snowpack of the Arctic coastal plain of Alaska using satellite data. J. Glaciol., 32, 87-94.

-, M. Sturm, C. S. Benson, A. T. C. Chang, J. L. Foster, H. Garbeil, and E. Chacho, 1991: Passive microwave remote and in situ measurements of Arctic and subarctic snow covers in Alaska. Rem. Sen. Envir., 38, 161-172.

Hall, S. J. 1986. Air Force Global Weather Central Snow Analysis Model. AFGWC/TN-86/001, 48 pp.

Hallikainen, M. T., and P. A. Jolma, 1986: Retrieval of the water equivalent of snow cover in Finland by satellite microwave radiometry. IEEE Trans. Geosci. Rem. Sen., GE-24, 855-862.

Intergovernmental Panel on Climate Change, 1992: Climate Change 1992: The Supplementary Report to the IPCC Scientific Assessment. Intergovernmental Panel on Climate Change. World Meteorological Organization. Cambridge Univ. Press, 200 pp.

Iwasaki, T., 1991: Year-to-year variation of snow cover area in the Northern Hemisphere. J. Meteor. Soc. Japan, 69, 209-217.

Jones, P. D., T. M. L. Wigley, and G. Farmer, 1991: Marine and land temperature data sets: A comparison and a look at recent trends. Greenhouse-Gas-Induced Climatic Change: A Critical Appraisal of Simulations and Observations. M. E. Schlesinger, Ed., Elsevier, 153-172.

Karl, T. R., P. Y. Groisman, R. R. Heim, Jr., and R. W. Knight, 1993: Recent variations of snow cover and snowfall in North America and their relation to precipitation and temperature variations. $J$. Climate, 6, 1327-1344.
Kukla, G., and D. A. Robinson, 1981: Accuracy of snow and ice monitoring. Snow Watch 1980, Glaciological Data, Report GD5, 91-97.

- R. G. Barry, A. Hecht, and D. Wiesnet, Eds., 1986: Snow Watch '85, Glaciological Data, Report GD-18, 276 pp.

Kunzi, K. F., S. Patil, and H. Rott, 1982: Snow-cover parameters retrieved from Nimbus-7scanning multichannel microwave radiometer (SMMR) data. IEEE Trans. Geosci. Rem. Sen., GE-20, 452-467.

Leathers, D. J., and D. A. Robinson, 1993: The association between extremes in North American snow cover extent and United States temperatures. J. Climate, 6, 1345-1355.

Matson, M., C. F. Ropelewski, and M. S. Varnadore, 1986: An Atlas of Satellite-derived Northern Hemispheric Snow Cover Frequency. NOAA, Washington, D.C., 75 pp.

McFarland, M. J., G. D. Wilke, and P. W. Harder II, 1987: Nimbus 7 SMMR investigation of snowpack properties in the northern Great Plains for the winter of 1978-1979. IEEE Trans. Geosci. Rem. Sen., GE-25, 35-46.

McGuffie, K., and D. A. Robinson, 1988: Variability of summer cloudiness in the Arctic Basin. Meteorol. Atmos. Physics, 39, 42-50.

Mitchell, J. F. B., S. Manabe, V. Meleshko, and T. Tokioka, 1990: Equilibrium climate change-And its implications for the future. Climate Change, The IPCC Scientific Assessment. Cambridge University Press, 131-172.

Nagler, T., and H. Rott, 1991: Intercomparison of snow mapping algorithms over Europe using SSM/I data. Interim Report to the SSM/I Products Working Team, 12.

Robinson, D. A., 1993a: Historical daily climatic data for the United States. Preprints, Eighth Conf. on Applied Climatology, Anaheim, CA, Amer. Meteor. Soc., 264-269.

_- 1993b: Monitoring Northern Hemisphere snow cover. Snow Watch 1992-Detection Strategies for Snow and lce: Glaciological Data Report GD-25, World Data Center A for Glaciology, University of Colorado, 1-25.

- and G. Kukla, 1985: Maximum surface albedo of seasonally snow covered lands in the Northern Hemisphere. J. Climate Appl. Meteor., 24, 402-411.

$\longrightarrow$, and K. F. Dewey, 1990: Recent secular variations in the extent of Northern Hemisphere snow cover. Geophys. Res. Let., 17, 1557-1560.

- and T. E. Spies, 1993: Monitoring snow cover on the Tibetan Plateau using microwave satellite data. Proc. ESANASA International Workshop on Passive Microwave Remote Sensing Research Related to Land-Atmosphere Interactions, SaintLary, France, in press.

- K. Kunzi, H. Rott, and G. Kukla, 1984: Comparative utility of microwave and shortwave satellite data for all-weather charting of snow cover. Nature, 312, 434-435.

- F. T. Keimig, and K. F. Dewey, 1991: Recent variations in Northern Hemisphere snow cover. Proc. 15th Annual Climate Diagnostics Workshop, Asheville, North Carolina, NOAA, 219224

-, M. C. Serreze, R. G. Barry, G. Scharfen, and G. Kukla, 1992: Interannual variability of snow melt and surface albedo in the Arctic Basin. J. Climate, 5, 1109-1119.

Schlesinger, M. E.; 1986: $\mathrm{CO}_{2}$-induced changes in seasonal snow cover simulated by the OSU coupled atmosphere-ocean general circulation model. Snow Watch '85, Glaciological Data, Report GD-18, 249-270.

Walsh, J. E., W. H. Jasperson, and B. Ross, 1985: Influences of snow cover and soil moisture on monthly air temperature. Mon. Wea. Rev., 113, 756-768.

Yasunari, T., 1987: Global structure of the El Niño/Southern Oscillation. Part II: Time evolution. J. Meteor. Soc. Japan, 65, 81-102. 